\title{
Faktor-Faktor Internal Kemenangan Partai Keadilan Sejahtera dalam Pemilihan Anggota DPRD Kota Depok Tahun 2019
}

\section{Internal Factors of the Winning of the Partai Keadilan Sejahtera in the Election of Depok City Parliament Members in 2019}

\author{
Muhammad Nuh Ismanu ${ }^{1 *}$, Chusnul Mar'iyah ${ }^{2}$ \\ ${ }^{1}$ Mahasiswa Pascasarjana Ilmu Politik, Fakultas Ilmu Sosial dan Ilmu Politik, Universitas \\ Indonesia, Gedung A Kampus UI Kota Depok, 16424, Indonesia \\ ${ }^{2}$ Dosen Ilmu Politik, Fakultas Ilmu Sosial dan Ilmu Politik, Universitas Indonesia, Gedung A \\ Kampus UI Kota Depok, 16424, Indonesia \\ *corresponding author E-mail : ismanu nunu@yahoo.com
}

Diterima: 9 September 2020; Direvisi: tgl 21 Oktober 2020; Disetujui: tgl 19 November 2020

\begin{abstract}
ABSTRAK
Sebagai suatu sistem politik di alam demokrasi keberadaan partai politik merupakan sebuah keharusan dalam kehidupan politik modern yang demokratis. Partai politik mampu mengantarkan warga negara untuk duduk di kursi pemerintahan baik legislatif maupun eksekutif. Dengan menggunakan teori strategi politik serta metode penelitian kualitatif, penelitian ini ingin melihat bagaimana faktor internal berpengaruh terhadap kemenangan Partai Keadilan Sejahtera (PKS) di pemilihan DPRD Kota Depok. Hasil dari penelitian ini memperlihatkan bahwa keberhasilan PKS dalam Pemilu 2019, khususnya pada pemilihan DPRD Kota Depok tidak lepas dari adanya pengaruh internal partai, yaitu ideologi Islam konservatif serta peran kader dan pengurus PKS Kota Depok. Ideologi Islam konservatif yang kurang diminati di Indonesia pasca reformasi kini mulai diminati seiring dengan menguatnya isu agama jelang pemilu serentak tahun 2019. Selain itu, faktor kader serta pengurus PKS Kota Depok juga menjadi salah satu kunci kemenangan PKS dalam pemilihan DPRD Kota Depok tahun 2019. Hal ini terlihat dari persiapan yang matang jelang pemilu.
\end{abstract}

Kata Kunci: Ideologi Islam konservatif, partai Islam, partai keadilan sejahtera, pemilihan DPRD kota Depok, strategi partai politik

\section{ABSTRACT}

As a political system in a democracy, the existence of political parties is a necessity in modern democratic political life. Political parties are able to lead citizens to sit in government, both legislative and executive. By using political strategy theory and qualitative research methods, this study wants to see how internal factors influence the victory of the Partai Keadilan Sejahtera (PKS) in the election of the Depok City Parliament. The results of this study indicate that 
the success of PKS in the 2019 election, especially in the Depok City parliament election, cannot be separated from the internal influence of the party, namely conservative Islamic ideology and the role of PKS cadres and administrators in Depok City. The conservative Islamic ideology that is less desirable in post-reform Indonesia is now starting to be in demand along with the strengthening of religious issues ahead of the 2019 simultaneous elections. In addition, the factor of cadres and PKS officials in Depok City is also one of the keys to PKS 'victory in the Depok City parliament election in 2019. This can be seen from the careful preparation ahead of the election.

Keywords: Conservative Islamic ideology, Islamic party, partai keadilan sejahtera, Depok city parliament election, political party strategy

\section{PENDAHULUAN}

Sebagai suatu sistem politik di alam demokrasi keberadaan partai politik merupakan sebuah keharusan dalam kehidupan politik modern yang demokratis. Partai politik di dalam negara demokrasi merupakan sebuah sarana bagi warga negara untuk dapat berpartisipasi dalam proses pengelolaan negara. Salah satu fungsi penting dari partai politik adalah sebagai sarana rekrutmen politik (Budiardjo, 2009, hal. 409). Rekrutmen partai politik menjadi fungsi utama partai dalam rangka menjalankan perannya sebagai penghubung antara warga negara dengan negara dalam bingkai representasi politik. Melalui rekrutmen politik, partai politik mampu mengantarkan warga negara untuk duduk di kursi pemerintahan baik legislatif maupun eksekutif (Siavelis \& Morgenstern, 2008, hal. 5-6). Oleh karena itu, penulis tertarik untuk meneliti bagaimana sebuah partai politik dapat memenangkan pemilu dan mengantarkan kadernya untuk meraih kekuasaan.

Telah banyak penelitian-penelitian sebelumnya yang melihat bagaimana partai politik dalam meraih kekuasaan atau memenangkan pemilu, khususnya di Indonesia. Seperti penelitian dari Debora Sanur Lindawati yang berjudul Strategi Partai Politik dalam Mengahadapi Pemilu 2014. Dalam penelitiannya Ia mengatakan bahwa dalam strategi pemenangan pemilu, partai politik perlu mengorganisir kegiatan kampanye secara kolektif. Secara internal, partai juga harus mengontrol belanja kampanye yang dikeluarkan 
POLITICON : Jurnal Ilmu Politik Vol.3 No.1 ; Hal 34 - 59

Website : http://journal.uinsgd.ac.id/index.php/politicon ISSN : 2685-6670 ( Online )

caleg maupun partai. Selain itu, partai juga harus menyusun pedoman etika berikut penegakannya berupa sanksi, jika kompetisi internal para caleg tidak sehat dan merusak (Lindawati, 2013, hal. 308-309).

Mengenai faktor pemenangan partai politik di tingkat lokal, terdapat penelitian dari Jonas Ricardo F. Sobalely yang berjudul Kemenangan Partai Demokrasi Indonesia Perjuangan (PDI-P) pada Pemilihan Umum Legislatif 2014 di Kota Depok. Dalam riset ini dijelaskan bahwa faktor-faktor penyebab kemenangan PDI-P pada Pemilu 2014 adalah ada dua faktor yaitu faktor eksternal dan internal. Faktor eksternal meliputi: mobilitas partai dengan isu populisme, identifikasi partai, dan sentimen politik. Faktor eksternal meliputi: peran pengurus kader PDI-P Kota Depok, strategi PDI-P Kota Depok, dan Tim Sukses PDI-P Kota Depok (Sobalely, 2015, hal. 112-119). Berdasarkan penelitian ini, penulis tertarik untuk melanjutkan penelitian tersebut dengan menggunakan wilayah penelitian yang sama yaitu Depok, namun objek penelitian yang berbeda yaitu PKS. Landasan utama mengapa penulis mengambil objek penelitian PKS karena pada pemilihan DPRD Kota Depok tahun 2019 tidak lagi dimenangkan oleh PDI-P dan telah berganti menjadi PKS. Berdasarkan data hasil pemilu (KPU Kota Depok, 2019), perolehan suara PKS dalam pemilu legislatif Kota Depok meningkat secara signifikan menjadi 211.949 suara $(20,81 \%)$ sehingga jumlah kursi PKS meningkat dua kali lipat menjadi 12 kursi. Untuk lebih jelas dapat dilihat pada grafik 1.

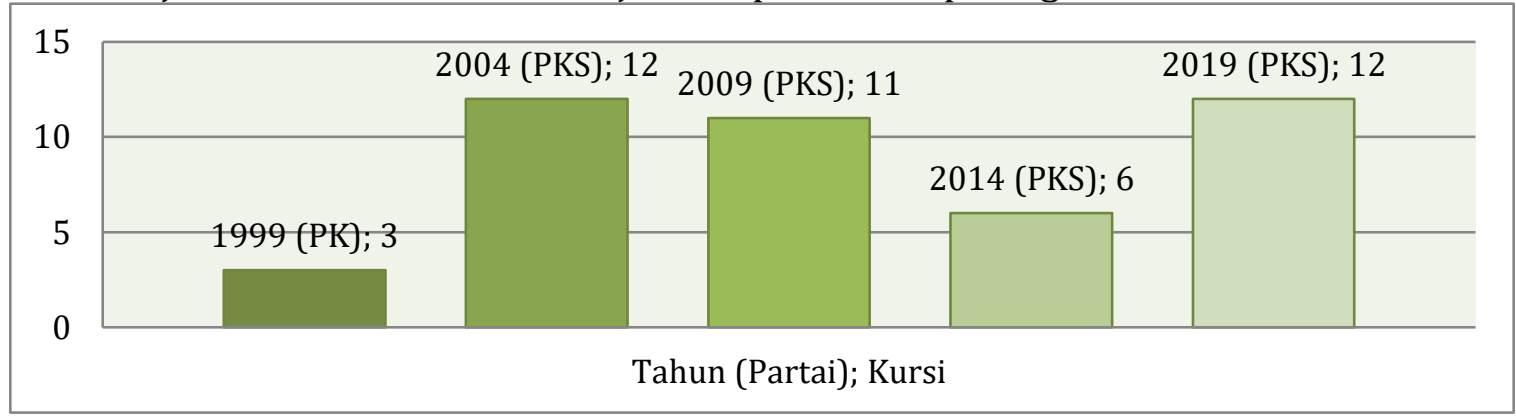

Grafik 1. Perolehan Kursi Partai Keadilan (PK) dan Partai Keadilan Sejahtera (PKS) dalam Pemilihan Anggota Dewan Perwakilan Rakyat Daerah (DPRD) Kota Depok Tahun 1999, 2004, 2009, 2014 dan 2019.

Sumber: Telah diolah kembali dari data KPU Kota Depok, Hasil Pileg Kota Depok Tahun 1999-2019. 
Selain objek penelitian, penelitian ini juga memiliki perbedaan, yaitu lebih terfokus kepada faktor internal PKS. Berdasarkan pengamatan penulis, terdapat dua variabel utama dalam membahas faktor internal PKS jika dikaitkan dengan pemenangan pada pemilihan DPRD Kota Depok, yaitu faktor ideologi dan program partai serta peran kader dan pengurus PKS Kota Depok.

Berdasarkan data di atas, perolehan suara PKS di kota Depok mengalami fluktuasi. Pada saat masih menjadi Partai Keadilan (PK) di awal masa reformasi, PKS hanya meraih 3 kursi di DPRD Kota Depok. Pada tahun 2004, naik menjadi 12 kursi setelah berubah nama menjadi Partai Keadilan Sejahtera (PKS). Pada tahun 2009 hingga tahun 2014, PKS mengalami kemerosotan suara menjadi 11 kursi dan 6 kursi. Barulah di Pemilu 2019, PKS mengalami kenaikan jumlah kursi yang signifikan menjadi 12 kursi.

Berbeda dengan penelitian dari Sobalely (2015) yang melihat kemenangan PDI-P secara lebih luas, penelitian ini hanya melihat faktor internal PKS. Menurut pendapat penulis, faktor internal PKS merupakan bagian terpenting dalam pemenangan PKS, yaitu pengaruh ideologi Islam konservatif dan peran dari kader dan pengurus PKS. Melansir dari hasil riset Lembaga Survei Indonesia bekerja sama dengan Australian National University (ANU) pada akhir tahun 2017 hingga awal tahun 2018, dijelaskan bahwa dalam PKS masuk dalam spektrum partai konservatif. Selain itu, PKS juga juga dinilai sebagai partai kedua yang paling memberikan dukungan terhadap peran Islam di dalam politik (Aspinall, Muhtadi, Fossati, \& Warburton, 2018). Untuk lebih jelas dapat dilihat pada gambar 1 dan 2.

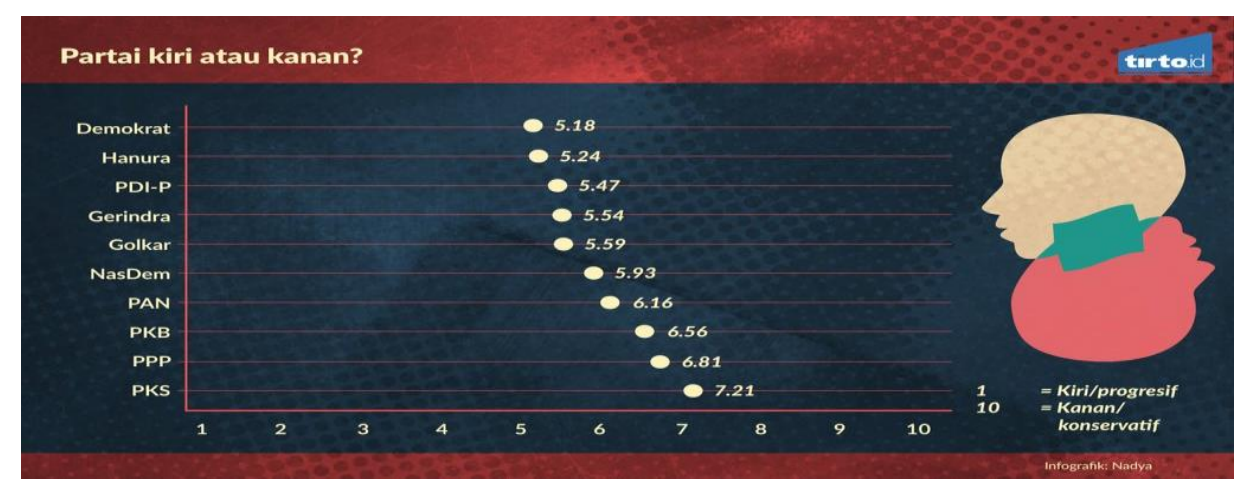

Gambar 1. Spektrum Partai Politik di Indonesia.

Sumber: Aspinall dkk, 2018 dalam Tirto.id. 


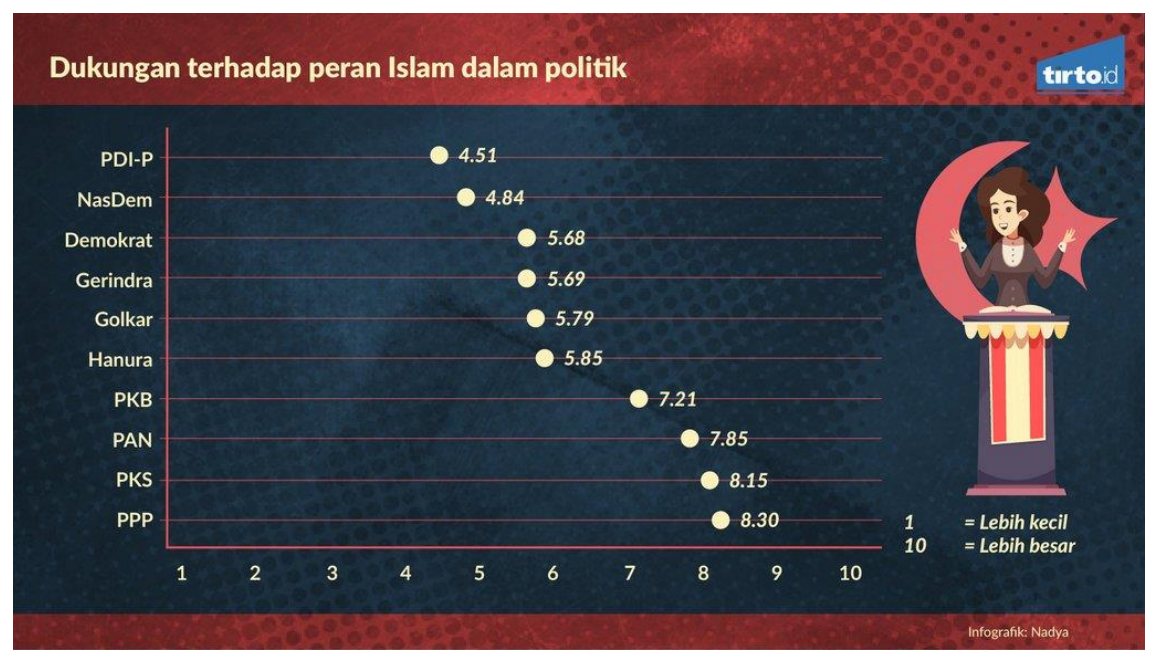

Gambar 2. Pandangan Partai Politik dalam Memberikan Dukungan Terhadap Peran Islam

Sumber: Aspinall dkk, 2018 dalam Tirto.id. dalam Politik.

Pembahasan mengenai Partai Islam juga dirasa menjadi perdebatan menarik dalam politik Indonesia. Sebagai salah satu elemen penting dalam pembelahan sosial, agama dipercaya bisa mempengaruhi perilaku pemilih dalam memilih partai politik. Lipset dan Rokkan (1967) dalam penelitiannya mengatakan bahwa terdapat korelasi signifikan antara afiliasi keagamaan dengan dukungan partai-partai konvensional di Eropa. Selain itu, ada penelitian dari Samuel Barnes (1974) yang mengatakan bahwa terdapat hubungan agama dengan perilaku pemilih di Italia (Muhtadi, 2012, hal. 199). Bagaimana pengaruh agama bagi perilaku pemilih di Indonesia? Karena mayoritas penduduk Indonesia adalah Muslim, maka variabel agama yang diulas dalam tulisan ini adalah pengaruh ideologi Islam.

Untuk membahas hal tersebut, maka penting untuk melihat mengenai politik aliran di Indonesia. Cliford Geertz dalam karyanya yang berjudul The Religion of Java memperkenalkan politik aliran di Indonesia. Menurut Geertz, kelompok abangan yang ia identifikasikan sebagai Muslim yang kurang taat cenderung memilih partai nasionalis atau sekuler atau komunis. Sedangkan kelompok santri dipercaya akan memilih Partai Islam (Geertz, 1976, hal. 370373). Walaupun banyak penelitian yang mengkritik politik aliran Geertz, namun teori politik aliran ini dapat menjelaskan secara kompleks perilaku pemilih islam di era 1950an. 
POLITICON : Jurnal Ilmu Politik Vol.3 No.1 ; Hal 34 - 59

Website : http://journal.uinsgd.ac.id/index.php/politicon ISSN : 2685-6670 ( Online )

Lalu bagaimana perilaku pemilih atau politik aliran pasca Reformasi? Secara faktual perolehan suara Partai Islam pada Pemilu 1999, 2004, dan 2009 mengalami penurunan jika dibandingkan dengan Pemilu 1955. Hal ini disebabkan karena kurang relevannya penjelasan mengenai politik aliran di Indonesia. Padahal, berdasarkan penelitian yang dilakukan oleh Lembaga Survei Indonesia (2003), Mershon Ohio State University dan UI (1999) dan Pusat Pengkajian Islam dan Masyarakat (2001 dan 2002) secara sosiologis telah terjadi peningkatan religiusitas di masyarakat namun tidak berdampak terhadap peningkatan suara Partai Islam (Muhtadi, 2012, hal. 201-202). Hal ini membuktikan adanya pergeseran pilihan dari pemilih Muslim di Indonesia, dari memilih Partai Islam menjadi memilih partai nasionalis. Hal ini sesuai dengan penelitian dari Sunny Tanuwidjaja yang mengatakan bahwa pemilih Muslim pasca Reformasi cenderung memilih partai nasionalis karena partai nasionalis juga mengakomodir nilai-nilai religiusitas (Tanuwidjaja, 2010, hal. 29-44).

Pada Pemilu 2019, suara Partai Islam cenderung mengalami kenaikan. Jika kita mengelompokan PAN, PKB, PKS dan PPP, hanya PAN yang mengalami penurunan jumlah kursi yaitu turun 5 kursi, sedangkan PKS naik 10 kursi dan PKB naik 11 kursi, lalu PPP yang tetap dengan 19 kursi. Kenaikan PKB diasumsikan karena keterpilihan KH. Ma'ruf Amin yang terpilih sebagai wakil presiden sehingga berdampak positif secara elektoral bagi partai pengusung. Oleh karena itu, penulis tertarik untuk menjadikan PKS sebagai objek penelitian. Untuk lebih lengkapnya dapat dilihat pada tabel 1.

Tabel 1. Jumlah Perolehan Kursi Partai Politik di DPR RI tahun 2014 dan 2019.

\begin{tabular}{lcc}
\hline \multicolumn{1}{c}{ Partai Politik } & \multicolumn{2}{c}{ Jumlah Kursi } \\
\cline { 2 - 3 } & $\mathbf{2 0 1 4}$ & $\mathbf{2 0 1 9}$ \\
\hline Partai Demokrasi Indonesia Perjuangan & 109 & 128 \\
Partai Golongan Karya & 91 & 85 \\
Partai Gerakan Indonesia Raya & 73 & 78 \\
Partai Demokrat & 61 & 54 \\
Partai Kebangkitan Bangsa & 47 & 58 \\
Partai Amanat Nasional & 49 & 44 \\
Partai Keadilan Sejahtera & 40 & 50 \\
Partai NasDem & 35 & 59 \\
Partai Persatuan Pembangunan & 19 & 19 \\
Partai Hati Nurani Rakyat & 16 & 0 \\
\hline
\end{tabular}

Sumber: Telah diolah kembali dari data KPU Kota Depok. 
POLITICON : Jurnal Ilmu Politik Vol.3 No.1 ; Hal 34 - 59

Website : http://journal.uinsgd.ac.id/index.php/politicon ISSN : 2685-6670 ( Online )

Penulis tertarik untuk menjadikan PKS sebagai objek penelitian. Sebab, seiring turunnya tren negatif Partai Islam pasca Reformasi, PKS justru berhasil meningkatkan perolehan jumlah kursi. Bahkan, di Kota Depok kenaikan tersebut mencapai 2 kali lipat. Dalam membahas Partai Islam maka ideologi menjadi faktor terpenting untuk dikaji. Oleh karena itu, penulis memilih untuk melihat faktor ideologi dan peran kader serta pengurus yang termasuk dalam faktor internal kemenangan PKS dalam pemilihan anggota DPRD Kota Depok tahun 2019. Penelitian ini akan menjawab pertanyaan: Bagaimana faktor internal dapat mempengaruhi kemenangan PKS dalam pemilihan DPRD Kota Depok?.

\section{METODE PENELITIAN}

Penelitian ini akan menggunakan metode penelitian kualitatif. Menurut John W. Creswell, penelitian kualitatif merupakan sebuah proses penyelidikan untuk memahami masalah sosial, berdasarkan pada penciptaan gambar holistik yang dibentuk dengan kata-kata, melaporkan pandangan informan secara terperinci dan disusun dalam sebuah latar ilmiah. Penelitian yang menggunakan metode kualitatif merupakan penelitian yang mengintrepretasikan data-data dengan cara memberi arti terhadap data yang diperoleh (Creswell, 2016, hal. iii \& 19). Oleh karena itu, dengan menggunakan metode penelitian kualitatif, peneliti dapat memperoleh data untuk memperdalam wawasan mengenai faktor internal kemenangan PKS dalam pemilihan DPRD Kota Depok tahun 2019.

Menurut W. Lawrence Neuman dalam penelitian kualitatif ada yang disebut dengan teori dan data. Data dan teori merupakan sebuah kesatuan dimana data yang diperoleh diliteraturkan, diinventarisir, dikualifikasikan, kemudian permasalahan digambarkan dengan fakta-fakta yang ada dan disusun dalam sebuah tulisan. Selain itu, penelitian ini juga menggunakan data sekunder, yaitu berupa literatur-literatur terkait penelitian. Literatur bisa didapat dari media cetak, media online, jurnal, penelitian-penelitian lainnya, website resmi partai politik ataupun website organisasi-organisasi nasional. 
POLITICON : Jurnal Ilmu Politik Vol.3 No.1 ; Hal 34 - 59

Website : http://journal.uinsgd.ac.id/index.php/politicon

ISSN : 2685-6670 ( Online )

Setelah data tersebut didapat, lalu data tersebut diolah dan dianalisis (Neuman, 2014, hal. 20-22).

Teknik analisis data dalam penelitian ini terdiri atas empat tahap. Pertama, data primer yang diperoleh dari wawancara dan data sekunder berupa dokumen-dokumen pendukung dipersiapkan dan disusun secara lengkap dalam satu berkas. Kedua, data yang telah disusun dalam satu berkas tesebut selanjutnya dianalisa dan dilakukan pencermatan sehingga dapat diketahui poin-poin utamanya. Ketiga, poin-poin utama yang telah didapatkan tersebut dikelompokkan sesuai dengan topik-topik pembahasan dalam penelitian ini untuk menjawab permasalahan di dalamnya namun pengelompokkan tersebut tidak membatasi relasi antara satu topik dengan topik lainnya. Keempat, data-data yang telah dikelompokkan disusun, dianalisis dan dinterpretasi sehingga dapat menjadi informasi yang memadai untuk memberikan kesimpulan dalam menjawab permasalahan yang ada pada setiap topik pembahasan dalam penelitian ini.

\section{HASIL DAN PEMBAHASAN}

Strategi politik adalah suatu mekanisme bagaimana seseorang ataupun kelompok dengan ide politik yang dipahaminya mampu untuk memenangkan suatu pertarungan politik disaat banyak orang yang berkepentingan menghendaki hal yang sama (Sobalely, 2015, hal. 20). Menurut Peter Schroder dalam merumuskan perencanaan strategi politik terdapat beberapa tahapan perencanaan yang harus dilalui, di antaranya merumuskan tugas, yaitu tujuan yang hendak dicapai, lalu menganalisa situasi, dan memetakan target konstituen. Setelah tahapan ini selesai, maka partai politik dapat membuat pesan yang hendak disampaikan (Schroder, 2010, hal. 107-118).

Berdasarkan teori ini, penulis mencoba untuk melihat tahapan strategi politik PKS di Pemilu 2019. Tahapan pertama adalah merumuskan tugas, yaitu tujuan yang hendak dicapai. Dalam skala nasional, Sekretaris Jenderal (Sekjen) PKS Mustafa Kamal mengatakan bahwa saat ini PKS dianggap sebagai partai papan tengah. Oleh karena itu, pada Pemilu tahun 2019 ia berharap PKS naik 
POLITICON : Jurnal Ilmu Politik Vol.3 No.1 ; Hal 34 - 59

Website : http://journal.uinsgd.ac.id/index.php/politicon ISSN : 2685-6670 ( Online )

tingkat menjadi partai papan atas. Lebih lanjut, ia mengatakan bahwa secara angka PKS menargetkan untung mendapatkan 12\% suara nasional atau sebesar 70 hingga 80 kursi di DPR RI (Ramadhan, 2017). Kemudian untuk di DPRD Kota Depok, Ketua DPD PKS Kota Depok Hafidz Nasir mengungkapkan target PKS adalah meraih minimal 11 kursi DPRD Kota Depok (Harian Sederhana, 2018).
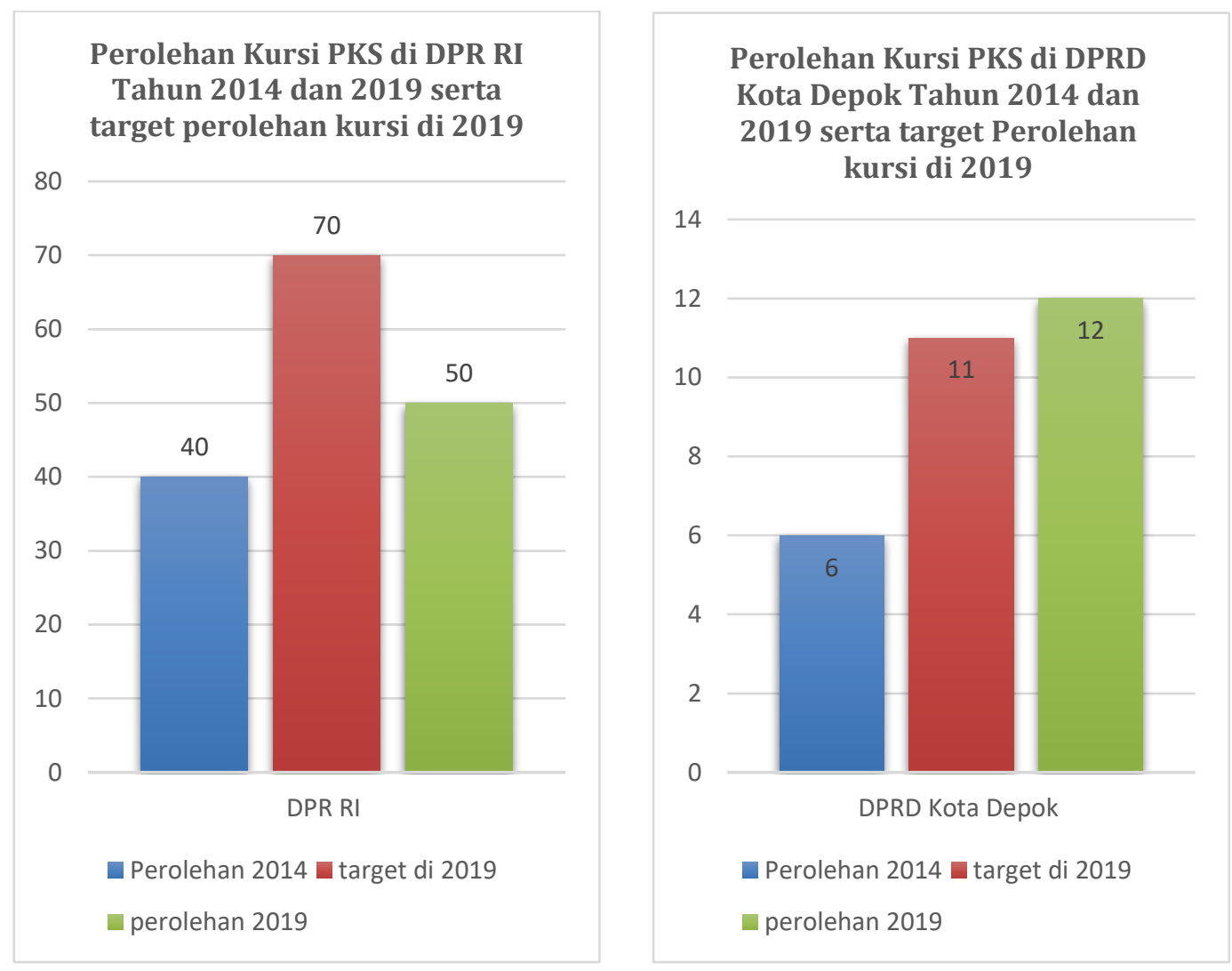

Grafik 2. Perolehan Kursi Partai Keadilan Sejahtera (PKS) dalam Pemilihan Anggota Dewan Perwakilan Rakyat Republik Indonesia (DPR RI) dan Anggota Dewan Perwakilan Rakyat

Daerah (DPRD) Kota Depok Tahun 2014 dan 2019 serta target kursi di pemilu 2019.

Sumber: Telah diolah kembali dari data KPU Kota Depok.

Tahapan kedua dalam teori strategi politik adalah menganalisa situasi. Pemilu 2019 adalah pemilu pertama kali dalam sejarah Indonesia yang dilaksanakan serentak dengan pemilihan presiden dan legislatif. Untuk itu, penentuan kebijakan partai mendukung presiden menjadi faktor penting. Sebab pemilih akan memilih partai yang mendukung calon presiden yang mereka pilih. Hal ini seperti teori ekor jas atau teori coattail effect, yaitu 
POLITICON : Jurnal Ilmu Politik Vol.3 No.1 ; Hal 34 - 59

Website : http://journal.uinsgd.ac.id/index.php/politicon ISSN : 2685-6670 ( Online )

terdapat hubungan antara popularitas calon presiden dengan partai pengusungnya. Artinya, seorang calon presiden atau presiden yang populer dengan tingkat elektabilitas yang tinggi akan memberikan keuntungan positif secara elektoral kepada partai yang mengusungnya sebagai calon (Hanan, 2018).

Hal ini sesuai dengan apa yang dikatakan oleh Ketua Dewan Pimpinan Pusat (DPP) PKS Mardani Ali Sera yang menyebutkan bahwa kenaikan perolehan suara PKS tidak terlepas dari konsistensi partai mendukung pasangan calon presiden dan wakil presiden Prabowo Subianto-Sandiaga Uno. Alhasil, pihaknya mendapat berkah elektoral. Lebih lanjut pengamat Politik dari Universitas Islam Nasional (UIN) Jakarta Adi Prayitno mengatakan pemilih Islam di kubu Prabowo-Sandi cenderung memilih PKS ketimbang partai Koalisi Indonesia Adil Makmur (Prabowo Subianto-Sandiaga Uno) lainnya. Sebab, PKS dinilai lebih tegas beroposisi ketimbang PAN dan Partai Demokrat (CNN Indonesia, 2019).

PKS juga diuntungkan dengan isu agama yang menguat pasca Pemilihan Gubernur DKI Jakarta dan adanya kasus penistaan agama yang dilakukan oleh Basuki Tjahaja Purnama (Ahok). Pakar hukum tata negara dari Pusat Studi Konstitusi Universitas Andalas, Khairul Fahmi, melihat isu agama masih menjadi faktor andalan yang berpotensi memicu konflik di Pemilu 2019 (Rahma, 2019). Bahkan, Partai Solidaritas Indonesia (PSI) yang menyerang dengan melontarkan sejumlah isu yang kerap berseberangan dengan PKS di era kampanye Pemilu 2019, seperti pelarangan poligami dan anti-Perda Syariah justru menjadi keuntungan sendiri bagi PKS. Keingintahuan masyarakat menjadi tumbuh terkait polemik antara kedua partai tersebut. Hal itu membuat masyarakat pada akhirnya membaca program-program yang ditawarkan PKS (CNN Indonesia, 2019).

Strategi ketiga adalah memetakan konstituten atau calon pemilih yang akan disasar. PKS adalah sebuah partai yang berideologikan Islam, oleh karena itu tentu saja sasaran dari PKS adalah pemilih Muslim. Dilansir dari tirto.id, 
POLITICON : Jurnal Ilmu Politik Vol.3 No.1 ; Hal 34 - 59

Website : http://journal.uinsgd.ac.id/index.php/politicon ISSN : 2685-6670 ( Online )

menurut Muttaqin Kepala Pemenangan Pemilu DPD PKS Kota Depok bahwa PKS mengamankan suara selama ini dengan memanfaatkan militansi dari para kader. Mesin partai bekerja dengan mendoktrin bahwa kampanye dalam pemilihan daerah dan nasional, baik kepala daerah maupun legislatif merupakan bagian dari ibadah (Putri, 2018).

Setelah mengetahui tujuan, menganalisa situasi, dan memetakan konstituten atau calon pemilih, PKS dapat dengan cermat memberikan pesan yang disampaikan kepada pemilihnya. Setidaknya ada 4 janji utama PKS di Pemilu 2019, di antaranya adalah membebaskan pajak motor ber-cc kecil, memberlakukan SIM seumur hidup, membebaskan pajak penghasilan di bawah Rp. 8 juta dan untuk konstituen muslim PKS berjanji akan memperjuangkan RUU Perlindungan Ulama dan Tokoh Agama (Fathurohman, 2019).

\section{Faktor Internal}

Berdasarkan penelitian yang dilakukan oleh Sobalely (2015), ia menemukan bahwa terdapat 2 hal yang dapat dilihat dalam menganalisa kemenangan partai politik dalam pemilu, yaitu internal dan eksternal. Namun penelitian ini menfokuskan kepada faktor internal PKS. Terdapat beberapa alasan mengapa penulis memilih faktor internal, di antaranya adalah bahwa PKS adalah partai yang berideologikan Islam konservatif. Selain itu, PKS lahir dari sebuah gerakan sosial bernama tarbiyah yang kemudian bermutasi menjadi partai politik. PKS tampil sebagai "partai kader" yang menerapkan standar ketat pada proses rekrutmen sehingga militansi para kader sudah tidak diragukan lagi (Muhtadi, 2012, hal. 31-54).

\section{Pengaruh Ideologi Islam Konservatif}

Faktor internal pertama yang akan dibahas adalah pengaruh ideologi dan program PKS terhadap kemenangan PKS di pemilihan DPRD Kota Depok. PKS merupakan salah satu partai politik yang berideologikan Islam. Hal ini terlihat di dalam Anggaran Dasar/Anggaran Rumah Tangga (AD/ART) BAB 1 Pasal 2 yang mengatakan bahwa PKS adalah partai yang berasaskan Islam. 
POLITICON : Jurnal Ilmu Politik Vol.3 No.1 ; Hal 34 - 59

Website : http://journal.uinsgd.ac.id/index.php/politicon ISSN : 2685-6670 ( Online )

Bahkan, di dalam misi partai disebutkan bahwa PKS menjadi sarana perwujudan masyarakat madani yang adil, sejahtera, dan bermartabat, yang diridhai oleh Allah subhanahu wa ta'ala dalam keutuhan negara kesatuan Republik Indonesia.

Seperti yang telah dijelaskan sebelumnya bahwa dalam tahap strategi politik, partai politik harus dapat membaca situasi dengan baik. Jika menarik mundur kebelakang, isu agama menjadi perhatian serius. Hal ini dimulai dengan adanya demonstrasi 2 Desember tahun 2016 atau yang kita kenal dengan istilah 212 atau aksi bela Islam. Aksi tersebut menuntut Gubernur DKI Jakarta nonaktif, Basuki Tjahaja Purnama (Ahok), yang telah ditetapkan sebagai tersangka dalam kasus dugaan penistaan agama.

Isu agama terus meningkat hingga satu tahun setelahnya, tepatnya pada momen Pilkada DKI Jakarta 2017. Pada Pilkada DKI Jakarta, PKS mendukung pasangan Anies Baswedan - Sandiaga S. Uno. Pasangan ini dinilai memiliki kedekatan dengan sejumlah ormas Islam, khususnya Front Pembela Islam (FPI). Hal ini terlihat dari kunjungan Anies Baswedan ke markas Front Pembela Islam di Petamburan, Jakarta Pusat, di hari pertama tahun 2017. Padahal, pada pemilihan presiden tahun 2014 lalu, Anies mengkritik kedekatan Prabowo dengan FPI yang disebutnya sebagai ekstremis. Namun bagi Halili Hasan, dosen sekaligus pengamat politik dari Universitas Negeri Yogyakarta (UNY) dan Setara Institute, manuver Anies adalah hal yang wajar. Ini semua menurutnya adalah bagian dari gerakan politik identitas berbasis agama untuk meraih suara elektoral. Ia pun menambahkan pendulum penggunaan sentimen agama di ruang publik ada di kubu Islam konservatif (Hasan, 2017). Sejak saat itu, kubu Islam konservatif memainkan peranan penting, termasuk PKS.

Dalam buku Dilema PKS yang ditulis oleh Burhanuddin Muhtadi (2012), jika dibandingkan partai Islam lain seperti PKB dan PAN, ceruk pemilih Muslim bagi PKS tergolong sedikit. PKB dan PAN didukung oleh dua ormas Islam terbesar di Indonesia, yaitu Nahdlatul Ulama (NU) dan Muhammadiyah. 
Namun sejak Pilkada DKI Jakarta, PKS menjalin hubungan yang harmonis dengan FPI. Hal ini terlihat dari kunjungan Ketua Majelis Syuro PKS Salim Segaf Al Jufrie didamping Ketua Fraksi PKS DPR RI Jazuli Juwaini dan sejumlah Elite PKS lainnya yang melakukan kunjungan silaturahmi ke Imam Besar FPI Rizieq Syihab di Makkah, Arab Saudi. Rizieq pun menyambut hangat kunjungan Elit PKS. Dalam kesempatan itu, Rizieq memberikan apresiasi dan penghargaan yang tinggi kepada PKS dan kader-kadernya yang telah bekerja keras dalam membela agama, bangsa, dan negara, serta mengawal amanah Ijtima' Ulama. Rizieq berharap agar PKS dapat memenangkan Pemilu 2019 (Nugroho, 2019). Kedekatan antara PKS dengan FPI menjadi salah satu alasan mengapa perolehan suara PKS meningkat di Pemilu 2019.

Di Kota Depok, isu agama juga menjadi perhatian serius masyarakat sejak era kepemimpinan Mohammad Idris. Mohammad Idris adalah walikota yang pada Pilkada 2015 didukung oleh PKS. Terdapat beberapa kebijakan kontroversial yang dikeluarkan Mohammad Idris yang berkaitan dengan hukum Islam, di antaranya adalah Perda tentang Peningkatan Ketahanan Keluarga. Sebagai turunan dari Perda Ketahanan Keluarga itu, Idris kemudian menerbitkan Instruksi Wali Kota Nomor 2/2018 tentang Penguatan Ketahanan Keluarga terhadap Perilaku Penyimpangan Seksual yang menyasar pada perilaku Lesbian, Gay, Biseksual, dan Transgender (LGBT) (Putri, 2019).

Selain itu, di awal tahun 2019 pemerintah Kota Depok mengeluarkan Rancangan Peraturan Daerah (Raperda) Syariah atau yang disebut dengan Raperda Penyelenggaraan Kota Religius (PKR) yang kemudian ditolak oleh DPRD Kota Depok. Raperda tersebut terdiri dari 20 pasal. Beberapa di antaranya mengatur cara beribadah, bersikap hingga berpakaian warga. Misalnya, Pasal 5 Ayat 4 dan 5 yang melarang perbuatan tercela seperti tindak pidana korupsi, perzinahan, pelacuran, mengonsumsi dan mengedarkan minuman beralkohol, aborsi, pornografi, riba, perbuatan syirik, eksploitasi anak dan perempuan, hingga penyebaran aliran sesat. Ada pula pasal yang mengatur etika berpakaian (Pasal 14 Ayat 1): Setiap orang wajib berpakaian 
POLITICON : Jurnal Ilmu Politik Vol.3 No.1 ; Hal 34 - 59

Website : http://journal.uinsgd.ac.id/index.php/politicon

ISSN : 2685-6670 ( Online )

sopan sesuai ajaran agamanya masing-masing dan norma kesopanan masyarakat Kota Depok (Putri, 2019).

Walaupun ditolak oleh DPRD Kota Depok, namun isu - isu ini menjadi cerminan pemikiran warga Kota Depok. Sebagian orang berpikirian bahwa Kota Depok sudah terlampau jauh dari moralitas, sehingga Perda Syariah menjadi sebuah solusi. Namun, ada pula sebagian masyarakat yang berpikir bahwa Perda Syariah mencederai hak kebebasan masyarakat Kota Depok. Dengan mencuatnya isu agama tersebut, maka PKS berusaha mengambil ceruk pemilih dari orang-orang yang berpikir bahwa Perda Syariah adalah solusi dan ingin menjadikan Kota Depok sebagai kota yang religius. Menurut Bonar Tigor Naipospos, Wakil Ketua Setara Institute bahwa akhirnya Perda syariah hanya digunakan sebagai instrumen politis untuk mengerek suara dan untuk memelihara dukungan kelompok tertentu (Putri, 2019).

Dari penjelasan di atas, Isu agama di DKI Jakarta yang menguat ternyata juga dirasakan di Kota Depok yang tidak jauh dari ibu kota. Hal inilah yang membuat partai-partai Islam, khususnya partai Islam konservatif seperti PKS berusaha mengambil ceruk pemilih yang berpikirian bahwa hukum syariah merupakan sebuah solusi. Selain itu, dengan adanya pemilu serentak tahun 2019, sehingga kenaikan suara nasional PKS dan isu-isu nasional yang digaungkan PKS berdampak positif bagi perolehan suara PKS di Kota Depok.

\section{Peran Strategi Kader dan Pengurus PKS}

Faktor internal kedua yang dibahas adalah peran kader dan pengurus PKS Kota Depok. Sebelum tahun 2019, PKS telah mulai menghidupkan dan memanaskan mesin politiknya. Dalam rangka persiapan menghadapi pemilu serentak tahun 2019, PKS menyelenggarakan forum-forum diskusi atau yang dikenal dengan istilah Forum Group Discussion (FGD). Seperti yang diselenggarakan pada tanggal 27 Juli 2017 di Ruang Rapat Pleno Fraksi PKS, Komplek Senayan. Pada FGD tersebut dibuka oleh Anggota DPR RI Fraksi PKS dari Dapil Jawa Barat VII, Mardani Ali Sera mengungkapkan kegiatan tersebut dalam rangka persiapan pemilu serentak 2019, Mardani juga mengungkapkan 
POLITICON : Jurnal Ilmu Politik Vol.3 No.1 ; Hal 34 - 59

Website : http://journal.uinsgd.ac.id/index.php/politicon ISSN : 2685-6670 ( Online )

bahwa diperlukan cara yang tepat untuk meningkatkan kemampuan pemetaan Daerah Pemilihan (Dapil) oleh seluruh struktur dan calon anggota legislatif dari PKS sebagai bagian dari strategi pemilu (Wiangga, 2017).

Setelah melaksanakan FGD, PKS membentuk Tim Pemenangan Pemilu (TPP) di seluruh wilayah Indonesia. TPP tersebut bersama dengan Manager Dapil dilantik pada hari Sabtu tanggal 25 November 2017 di Kantor DPP PKS. Pelantikan tersebut dilakukan langsung oleh Presiden PKS, Muhammad Sohibul Iman. Selain melantik TPP dan Manager Dapil, Presiden PKS juga menyampaikan pembekalan sebagai masukan dalam persiapan pemilu serentak 2019 kepada calon anggota DPR-RI dari PKS. Dalam materi pembekalan tersebut, diantaranya Presiden PKS mengingatkan keikhlasan niat kepada Tuhan, keteguhan sikap pada nilai-nilai partai sebagai pembeda antara PKS dengan partai lainnya, yaitu:

"Kita harus senatiasa memperbaiki niat, karena dengan lurusnya niat maka pertolongan Allah akan hadir kepada kita. Kita memiliki nilai-nilai, dan kita harus teguh pada nilai-nilai tersebut. Kita harus menang dengan penuh keberkahan, itu adalah prinsip kita. Kita tidak boleh menang dengan cara-cara yang tidak halal, itu adalah prinsip kita. Kita memiliki cara yang berbeda dengan orang lain dalam berpolitik. Bagi kita, berpolitik tidak hanya semata merebut kekuasaan, namun untuk merealisasikan cita-cita bersama untuk Indonesia" (Humas DPP PKS, 2017).

Setelah pembentukan TPP, selanjutnya PKS menyelenggarakan konsolidasi akbar nasional di Hotel Bumi Wiyata yang berada di Jalan Raya Margonda Depok Jawa Barat PKS pada tanggal 14 Oktober 2018. Dalam acara tersebut juga hadir Ketua Majelis Syuro PKS (Salim Segaf Aljufri), Presiden PKS (Muhammad Sohibul Iman), Caleg DPR-RI PKS dan para Kepala Daerah dari PKS. Pada acara tersebut Direktur Pencapresan PKS (Suhud Alynudin) menyatakan bahwa di antara agenda yang dibahas adalah mengenai konsolidasi struktur dan calon anggota legislatif DPR RI, pemenangan pilpres dan fokus pembahasan pada pemenangan PKS pada pemilu legislatif (Riana, 2018). 
POLITICON : Jurnal Ilmu Politik Vol.3 No.1 ; Hal 34 - 59

Website : http://journal.uinsgd.ac.id/index.php/politicon ISSN : 2685-6670 ( Online )

Acara konsolidasi nasional tersebut diikuti oleh lebih dari 1.000 peserta yang terdiri dari Dewan Pimpinan Tingkat Pusat (DPTP) dan Dewan Pimpinan Tingkat Pusat (DPTW), tim pemenangan dan para calon anggota legislatif. Tujuan dari kegiatan tersebut juga sebagai bagian strategi PKS dalam mencapai targetnya menjadi partai papan atas dalam Pemilu 2019. Dalam konsolidasi nasional ini, keinginan PKS untuk menjaga integritas pemilu diwujudkan dengan memberikan pembekalan kepada para calegnya agar tidak melakukan kecurangan pemilu (Mansur, 2018).

Dalam menguatkan kader dan para caleg demi memenangkan Pemilu 2019, PKS melakukan pendidikan politik. Pendidikan politik dalam internal PKS disebut dengan halaqah (mentoring). Pendidikan politik juga merupakan bagian dari langkah-langkah dalam penguatan partai politik. Pendidikan politik diharapkan dapat membentuk kepribadian politik, kesadaran politik dan kemampuan anggota untuk berpartisipasi aktif dalam politik (Labolo \& Ilham, 2015, hal. 227-239).

Penguatan partai politik dalam pendidikan politik dapat dilakukan dalam tiga langkah. Pertama adalah penguatan ideologi. Pendidikan politik diharapkan dapat memberikan kemampuan kadernya untuk mengimplementasikan ideologi tersebut sehingga dapat menjawab persoalanpersoalan yang terjadi ditengah masyarakat dan pada akhirnya ideologi tersebut dapat diterima oleh masyarakat. Tahapan kedua adalah penguatan kaderisasi partai. PKS merupakan partai kader, yang artinya bergantung pada militansi kadernya. Oleh karena itu, penguatan kaderisasi partai merupakan suatu langkah penting guna memenangkan pemilu. Selain itu, dengan pendidikan politik diharapkan dapat memberikan kemampuan kadernya untuk dapat bersaing dengan kader dari partai lainnya. Tahapan ketiga adalah pendanaan partai. Pendidikan politik diharapkan dapat memberikan kesadaran bagi anggota untuk dapat menyalurkan iuran anggota secara sukarela karena kedekatan emosionalnya untuk kesuksesan partai sehingga pengelolaan partai dalam hal pendanaan menjadi lebih baik dan mandiri tidak 
hanya mengandalkan bantuan negara.

Setelah pembekalan kader dan caleg dirasa telah cukup, maka penting untuk melihat bagaimana mesin politik PKS bekerja. Salah satu strategi kampanye PKS adalah dengan memberikan pendidikan politik kepada masyarakat. Pendidikan politik yang diselenggarakan oleh PKS diterapkan pada seluruh tingkatan partai baik di tingkat DPP (Dewan Pimpinan Pusat), DPD (Dewan Pimpinan Daerah) tingkat Provinsi dan Kabupaten/Kota, DPC (Dewan Pimpinan Cabang) tingkat Kecamatan dan DPRa (Dewan Pimpinan Ranting) tingkat Ranting atau Kelurahan. Sebagaimana diungkapkan oleh Ketua Majelis Pertimbangan Pusat PKS (Drs. H. Suharna Surapranata, M.T, 2008), bahwa:

"Dalam bingkai pemilu, maka para juru kampanye sebuah partai wajib menguasai betul pesan utama platform yang ingin diperjuangkannya, kemudian mengkomunikasikan semua pesan itu kepada masyarakat konstituen secara baik. Pilihan kata yang tepat, metoda penyampaian yang menarik, dan pemaparan buktibukti yang meyakinkan akan mengarahkan pilihan suara konstituen. Itulah cara rasional dan elegan dalam menjaring suara, bukan dengan sogokan politik uang atau intimidasi kekerasan fisik dan psikologis. Selain itu untuk meyakinkan publik perlu dimunculkan tokoh sebagai ikon dari masing-masing bidang platform ini. Inilah kewajiban calon anggota legislatif dan juru kampanye PK Sejahtera di pusat maupun daerah, menyebarluaskan platform kebijakan pembangunan PK Sejahtera ke segenap pelosok Tanah Air hingga ke mancanegara. Sekali lagi, harapan kami gunakan "bahasa kaum", bahasa yang mudah dan akrab di telinga masyarakat, namun tetap cerdas dan visioner. Jangan sampai ada lapisan masyarakat yang tidak mengenal atau memahami apa sesungguhnya yang diperjuangkan PK Sejahtera. Forum dialog warga, debat publik, atau wawancara di media massa dapat dimanfaatkan sebagai sarana penyebaran ide platform ini." (Majelis Pertimbangan Pusat Partai Keadilan Sejahtera, 2008, hal. xiv-xv).

Pendidikan politik menjadi bagian dalam program kerja bidang kaderisasi, keummatan dan kebijakan publik. Dalam bidang kaderisasi pendidikan politik dilakukan melalui kegiatan pelatihan dan pembinaan seperti taklim (pengajaran tentang keaagamaan Islam dan pengajian) secara rutin kepada anggota pemula, anggota muda dan calon anggota serta 
POLITICON : Jurnal Ilmu Politik Vol.3 No.1 ; Hal 34 - 59

Website : http://journal.uinsgd.ac.id/index.php/politicon ISSN : 2685-6670 ( Online )

masyarakat umum, kegiatan seminar dan kegiatan kajian serta kegiatan sosial.

Dalam bidang keummatan pendidikan politik dilakukan melalui kerjasama dan silaturahmi kepada tokoh masyarakat dan tokoh agama dalam tiga pendekatan, yaitu: dakwah (dalam pengajian atau Taklim secara rutin maupun dalam ceramah-ceramah shalat berjamaah ditempat ibadah umum seperti Masjid dan Musholla); pendidikan seperti pendampingan lembaga pendidikan maupun lembaga pendidikan baru; dan kerjasama dengan lembaga maupun organisasi masyarakat (ormas) seperti silaturahmi antar lembaga dakwah atau dengan merekrut tokoh dan mendukung kadernya masuk dalam lembaga dan organisasi masyarakat tertentu. Dalam bidang kebijakan publik pendidikan politik dilakukan melalui penjelasan dalam reklame seperti spanduk dan penerbitan publikasi cetak secara rutin seperti bulletin, kemudian melalui internet yaitu website resmi dan media sosial (Ashar, 2011, hal. 75-80).

Pendidikan politik melalui dakwah politik (siyasah) dapat diartikan sebagai kegiatan pengajaran keagamaan Islam yang menjadikan kekuasaan, birokrasi dan kekuatan politik untuk kepentingan misi Islam. Dakwah politik yang diprogramkan PKS adalah melalui pola struktural yaitu dengan mendorong terciptanya regulasi maupun kebijakan yang sesuai dengan ajaran Islam dan juga melalui pola kultural yaitu dengan pemberdayaan ummat dalam kelompok tarbiyah (pembinaan dan bimbingan) secara rutin dan persuasif seperti dalam lingkungan keluarga, kelompok studi terbatas atau pertemuan mingguan kemudian rekreasi, pelatihan dan seminar. Pembinaan dalam pola kultural dengan memanfaatkan kegiatan adat, tradisi daerah masing-masing sesuai kegiatan dilaksanakan (Supriatna, Amin, \& Jasad, 2016, hal. $18-19 \& 32)$.

Pendidikan politik yang diselenggarakan PKS dikenal juga dengan konsep Manhaj Tarbiyah, yaitu membentuk kepribadian Islami kader berdasarkan parameter yang dikenal dengan muwashofat tarbawiyah yang selanjutnya akan menjadi pertimbangan dalam penilaian terhadap 
POLITICON : Jurnal Ilmu Politik Vol.3 No.1 ; Hal 34 - 59

Website : http://journal.uinsgd.ac.id/index.php/politicon ISSN : 2685-6670 ( Online )

penempatan jenjang dan amanah dalam partai yang akan diberikan kepada kader. Aspek-aspek muwashofat tarbawiyah terdiri dari 10 aspek, yaitu beraqidah lurus, beribadah dengan benar, berakhlak kokoh, mampu berpenghasilan, memiliki pikiran yang berwawasan, bertubuh sehat dan kuat, memiliki jiwa yang bersungguh-sungguh, mampu mengatur rapih segala urusan, mampu mengatur waktu, dan bermanfaat untuk orang lain (Sholeh, 2015, hal. 56 \& 65).

Strategi lainnya dari penyelenggaraan pendidikan politik yang dilakukan oleh PKS terhadap internal dan eksternalnya adalah dengan mendorong dilibatkannya kalangan perempuan. Sebagaiman diungkapkan Presiden PKS, Muhammad Sohibul Iman bahwa masyarakat dipandang perlu untuk diberikan pendidikan politik dan sentuhan perempuan memiliki peran penting karena dapat membuat masyarakat lebih teredukasi (NAS, 2018).

Berdasarkan penjelasan tersebut di atas, pendidikan politik yang diselenggarakan oleh PKS meningkatkan kemampuan dan keahlian para kader dalam menjalankan tugasnya sebagai bagian dari organisasi partai sekaligus membentuk kepribadian Islami yang kemudian meningkatkan kesetiaan para kader terhadap PKS yang juga berasaskan Islam. Pendidikan dalam hubungannya dengan kontestasi pemilu diarahkan oleh Ketua Majelis Pertimbangan Pusat PKS sebagai bagian dalam pemantapan pemahaman para kader dan pengurus terhadap platform dan program yang telah dirumuskan sebelumnya sehingga para kader maupun pengurus tersebut kemudian mampu mentransfer pemahaman tersebut dan meyakinkan dengan bahasa yang mudah dipahami kepada para pemilih dan pendukungnya untuk memberikan suaranya kepada PKS pada saat pemilu. Simpati pemilih dan kemenangan diperoleh melalui cara yang dianggap terhormat dan tidak melanggar kejahatan pemilu seperti politik uang dan intimidasi lawan politik. Berikutnya pemberdayaan perempuan dalam pendidikan politik mematahkan kesan atau isu tentang kekhawatiran dominasi laki-laki dalam partai yang berasaskan Islam sehingga membuka kesan terbuka terhadap partisipasi 
pemilih dari kaum perempuan.

Di samping menjalankan pendidikan politik, PKS juga melakukan sosialisasi politik dalam bentuk indoktrinasi politik, sebagaimana diungkapkan oleh Ketua Bidang Pemenangan Pemilu dan Pemilukada, Muttaqin Syafi'i:

"Pamungkas PKS mengamankan suara selama ini dengan memanfaatkan militansi dari para kader. Mesin partai itu bekerja dengan mendoktrin bahwa kampanye dalam pemilihan daerah dan nasional baik kepala daerah maupun legislatif merupakan bagian dari ibadah. Sehingga kader PKS bukan hanya berkorban waktu, tenaga, dan pikiran, tapi juga finansial. Selain itu, pendekatan PKS melalui ideologis. Mereka mendekati konstituen lewat penyadaran dan pemahaman, bukan pertama-tama lewat politik uang. Sebab, jika bermodal politik uang, PKS akan kalah total karena modal yang minim. Pengaruh PKS di Depok menyentuh ke diskusi-diskusi informal di kampus dan kelompok Tarbiyah. Kaderisasi sudah dilakukan sejak dini. Demografi masyarakat Depok adalah kelas menengah berpendidikan tinggi." (Putri, 2018).

Suksesnya strategi kampanye PKS tentunya tidak hanya didukung oleh pilihan bentuk sosialisasi politik dan metode kampanye yang diterapkan, tetapi juga kemampuan PKS dalam menyediakan anggaran (pendanaan kampanye). Kemampuan pendanaan kampanye adalah sebagai bagian penting dalam menunjang kesuksesan strategi kampanye, yaitu sebagai upaya memenuhi kebutuhan sumber daya yang diperlukan partai untuk melaksanakan strategi kampanye yang telah direncanakan sehingga pelaksanaan kampanye sesuai tujuan atau target yang diharapkan dan pada tujuan akhirnya dapat menarik simpati pemilih.

Pendanaan kampanye dapat berupa uang maupun barang modal yang berasal dari internal partai maupun sumbangan pihak luar seperti simpatisan atau pendukung sesuai ketentuan pemilu yang berlaku. Maka dalam hal pendanaan kampanye tidak hanya sebatas penyediaan kedua modal materi tersebut namun juga diperlukan kemampuan pengelolaan dan pemanfaatannya agar tidak hanya menyukseskan program kampanye tetapi juga sesuai aturan main pemilu. 
POLITICON : Jurnal Ilmu Politik Vol.3 No.1 ; Hal 34 - 59

Website : http://journal.uinsgd.ac.id/index.php/politicon ISSN : 2685-6670 ( Online )

Tabel 2. Hasil Audit Laporan Dana Kampanye Partai Politik Peserta Pemilu

\begin{tabular}{|c|c|c|c|c|c|c|}
\hline \multirow[b]{2}{*}{$\mathbf{o}$} & \multirow[b]{2}{*}{ Partai Politik } & \multirow{2}{*}{$\begin{array}{l}\mathbf{K} \\
\mathbf{u} \\
\mathbf{r} \\
\mathbf{s} \\
\mathbf{i}\end{array}$} & \multicolumn{4}{|c|}{ Hasil Audit Laporan Penerimaan dan Pengeluaran Dana Kampanye (LPPDK) } \\
\hline & & & $\begin{array}{c}\text { Jumlah Calon Anggota } \\
\text { DPRD Yang } \\
\text { Menyerahkan }\end{array}$ & $\begin{array}{c}\text { Jumlah Calon } \\
\text { Anggota DPRD Yang } \\
\text { Tidak Menyerahkan }\end{array}$ & Total Penerimaan & Total Pengeluaran \\
\hline 1 & Partai Keadilan Sejahtera (PKS) & 12 & 50 Calon & 0 Calon & 3.189.283.400 & 3.172 .048 .400 \\
\hline 2 & Partai Gerakan Indonesia Raya (Partai Gerindra) & 10 & 50 Calon & 0 Calon & 5.113 .707 .080 & 5.113 .707 .080 \\
\hline 3 & Partai Demokrasi Indonesia Perjuangan (PDI-P) & 10 & 50 Calon & 0 Calon & 1.318 .615 .000 & 1.318 .615 .000 \\
\hline 4 & Partai Golongan Karya (Partai Golkar) & 5 & 48 Calon & 0 Calon & 1.895 .449 .140 & 1.052 .949 .140 \\
\hline 5 & Partai Amanat Nasional (PAN) & 4 & 50 Calon & 0 Calon & 1.474 .489 .067 & 1.473 .587 .013 \\
\hline 6 & Partai Kebangkitan Bangsa (PKB) & 3 & 14 Calon & 33 Calon & 1.793 .795 .471 & 1.187 .206 .460 \\
\hline 7 & Partai Demokrat & 3 & 50 Calon & 0 Calon & 557.120 .000 & 557.120 .000 \\
\hline 8 & Partai Persatuan Pembangunan (PPP) & 2 & 45 Calon & 0 Calon & 1.928 .975 .000 & 1.927 .975 .000 \\
\hline 9 & Partai Solidaritas Indonesia (PSI) & 1 & 49 Calon & 0 Calon & 334.187 .645 & 334.187 .645 \\
\hline 10 & Partai NasDem & 0 & 49 Calon & 1 Calon & 21.000 .000 & 20.000 .000 \\
\hline 11 & Partai Berkarya & 0 & 50 Calon & 0 Calon & 522.892 .675 & 522.892 .675 \\
\hline 12 & Partai Persatuan Indonesia (Partai Perindo) & 0 & 17 Calon & 11 Calon & 351.757 .400 & 184.865 .400 \\
\hline 13 & Partai Hati Nurani Rakyat (Partai Hanura) & 0 & - & - & - & - \\
\hline 14 & Partai Bulan Bintang (PBB) & 0 & 23 Calon & 0 Calon & 5.230 .056 & 5.230 .056 \\
\hline 15 & $\begin{array}{l}\text { Partai Gerakan Perubahan Indonesia (Partai } \\
\text { Garuda) }\end{array}$ & 0 & - & - & - & - \\
\hline 16 & Partai Keadilan dan Persatuan Indonesia (PKPI) & 0 & 3 Calon & 0 Calon & 16.295 .000 & 16.295 .000 \\
\hline & Total & 50 & 548 Calon & 45 Calon & 18.522 .796 .934 & 16.886 .678 .869 \\
\hline
\end{tabular}

Sumber: Telah diolah kembali dari data KPU Kota Depok.

Berdasarkan tabel 2 dapat diketahui bahwa dari 16 partai politik yang mengikuti kontestasi pemilu legislatif tahun 2019 di Kota Depok, PKS termasuk dari beberapa partai yang seluruh calegnya menyerahkan laporan dana kampanye kepada partainya. Kemudian untuk transaksi penerimaan dana kampanye yang mencapai nilai 1 miliar rupiah ke atas, PKS berada pada urutan kedua dengan nilai lebih dari 3 miliar rupiah setelah Partai Gerindra dengan nilai lebih dari 5 miliar rupiah. Dalam hal transaksi pengeluaran dana kampanye yang mencapai nilai 1 miliar rupiah ke atas, PKS juga berada pada urutan kedua dengan nilai lebih dari 3 miliar rupiah setelah Partai Gerindra dengan nilai lebih dari 5 miliar rupiah yang kemudian disusul dengan urutan selanjutnya dengan nilai di bawah 2 miliar rupiah adalah PPP, PAN, PDI-P, PKB dan Partai Golkar. Besarnya nilai penerimaan dan pengeluaran dana kampanye PKS yang berada pada peringkat dua tersebut menunjukkan bahwa PKS memiliki kemampuan pendanaan untuk menunjang kegiatan-kegiatan kampanye yang cukup signifikan nilainya dalam jajaran partai-partai yang 
POLITICON : Jurnal Ilmu Politik Vol.3 No.1 ; Hal 34 - 59

Website : http://journal.uinsgd.ac.id/index.php/politicon ISSN : 2685-6670 ( Online )

bertarung dalam kontestasi pemilu legislatif tahun 2019 di Kota Depok.

Dari penjelasan ini penulis melihat peran kader, pengurus, serta caleg cukup baik sehingga berhasil meningkatkan performa partai di pemilihan DPRD Kota Depok tahun 2019. Berikut dipaparkan daftar caleg terpilih PKS Kota Depok:

Tabel 3. Hasil Daftar Calon Anggota Legislatif (Caleg) Terpilih dari Partai Keadilan Sejahtera (PKS) di Seluruh Daerah Pemilihan (Dapil) pada Pemilu Dewan Perwakilan Rakyat Daerah (DPRD) Kota Depok Tahun 2019.

\begin{tabular}{|c|c|c|}
\hline No. & Caleg Terpilih & Daerah Pemilihan \\
\hline 1 & H. Moh. Hafid Nasir & \multirow{2}{*}{ Dapil 1 (Kecamatan Pancoran Mas) } \\
\hline 2 & H. Imam Musanto & \\
\hline 3 & H. T.M. Yusufsyah Putra & \multirow{2}{*}{ Dapil 2 (Kecamatan Beji, Cinere dan Limo) } \\
\hline 4 & T. Farida Rachmayanti & \\
\hline 5 & Ade Supriyatna, S.T & \multirow{2}{*}{ Dapil 3 (Kecamatan Cimanggis) } \\
\hline 6 & Dra. Sri Utami, M.M & \\
\hline 7 & H. M. Supariyono & \multirow{2}{*}{ Dapil 4 (Kecamatan Sukmajaya) } \\
\hline 8 & Hengky, S.T & \\
\hline 9 & Qurtifa Wijaya, S.Ag & \multirow{2}{*}{ Dapil 5 (Kecamatan Tapos dan Cilodong) } \\
\hline 10 & Ade Firmansyah, S.H & \\
\hline 11 & Habib Syarif Gasim H. & \multirow{2}{*}{ Dapil 6 (Kecamatan Sawangan, Bojongsari dan Cipayung) } \\
\hline 12 & H. Khairulloh & \\
\hline
\end{tabular}

Sumber: Telah diolah kembali dari data KPU Kota Depok.

Berdasarkan tabel di atas dapat diketahui bahwa dari seluruh Dapil (6

Dapil) di Kota Depok sebaran perolehan kursi PKS dapat dikatakan merata yaitu masing-masing di setiap Dapilnya berhasil memperoleh 2 kursi sehingga total menjadi 12 kursi. Terbukti bahwa 5 Caleg Petahana yang maju kembali pada pemilu DPRD Kota Depok pada pemilu serentak 2019 telah berhasil terpilih kembali yaitu: Dra. Sri Utami, M.M dari Dapil 3 (Kecamatan Cimanggis), Qurtifa Wijaya, S. Ag dari Dapil 5 (Kecamatan: Cilodong dan Tapos), T. Farida Rachmayanti dari Dapil 2 (Kecamatan: Beji, Cinere dan Limo), H. M. Supariyono dari Dapil 4 (Kecamatan Sukmajaya), dan H. Moh. Hafid Nasir dari Dapil 1 (Kecamatan Pancoran Mas).

\section{SIMPULAN}

Keberhasilan PKS dalam Pemilu 2019, khususnya pada pemilihan DPRD Kota Depok, tidak lepas dari adanya pengaruh internal partai, yaitu ideologi Islam konservatif serta peran kader dan pengurus PKS Kota Depok. Ideologi Islam konservatif yang kurang diminati di Indonesia pasca Reformasi kini mulai diminati seiring dengan menguatnya isu agama jelang pemilu serentak tahun 2019. Selain itu, hubungan PKS dengan FPI yang memiliki 
POLITICON : Jurnal Ilmu Politik Vol.3 No.1 ; Hal 34 - 59

Website : http://journal.uinsgd.ac.id/index.php/politicon ISSN : 2685-6670 ( Online )

corak yang sama juga memberi dampak positif bagi performa PKS pada Pemilu 2019 jika dilihat dari perolehan jumlah kursi.

PKS yang lahir dari sebuah gerakan sosial dan juga termasuk ke dalam partai kader tentu memiliki kader-kader yang militan. Oleh karena itu, faktor kader serta pengurus PKS Kota Depok juga menjadi salah satu kunci kemenangan PKS dalam pemilihan DPRD Kota Depok tahun 2019. Hal ini terlihat dari persiapan yang matang jelang pemilu, mulai dari adanya Forum Group Discussion (FGD), konsolidasi nasional, serta pendidikan politik baik untuk kader, pengurus, caleg, maupun masyarakat secara umum. Selain itu, PKS Kota Depok juga memiliki kekuatan finansial yang memadai guna memenangkan pemilu yang terlihat dari transaksi penerimaan dan pengeluaran partai untuk pemilihan DPRD Kota Depok.

\section{DAFTAR PUSTAKA}

Ashar, A. S. (2011). Pelaksanaan Pendidikan Politik Oleh DPD Partai Keadilan Sejahtera (PKS) Kabupaten Semarang. Skripsi. Semarang: Hukum dan Kewarganegaraan Fakultas Ilmu Sosial Universitas Negeri Semarang.

Aspinall, E., Muhtadi, B., Fossati, D., \& Warburton, E. (2018, Mei 3). Corak Ideologi Partai-Partai di Indonesia. Diambil kembali dari Tirto.id: https://tirto.id/corak-ideologi-partai-partai-di-indonesia-cJKc

Budiardjo, M. (2009). Dasar - Dasar Ilmu Politik. Jakarta: PT. Gramedia Pustaka Utama.

CNN Indonesia. (2019, Mei 24). Buah Manis Ketegasan PKS Jadi Oposisi. From Cnnindonesia.com:

https://www.cnnindonesia.com/nasional/20190520180040-32-

396591/buah-manis-ketegasan-pks-jadi-oposisi

Creswell, J. W. (2016). Research Design: Pendekatan Metode Kualitatif, Kuantitatif, dan Campuran (Edisi Keempat). Yogyakarta: Pustaka Pelajar.

Fathurohman, I. (2019, November 19). Mengingat Empat Janji PKS di Pemilu 2019. From IDN Times: https://www.idntimes.com/news/indonesia/irfanfathurohman/mengi ngat-empat-janji-pks-di-pemilu

Geertz, C. (1976). The Religion of Java. Chicago: University of Chicago. 
POLITICON : Jurnal Ilmu Politik Vol.3 No.1 ; Hal 34 - 59

Website : http://journal.uinsgd.ac.id/index.php/politicon ISSN : 2685-6670 ( Online )

Hanan, D. (2018, Februari 19). Efek Ekor Jas. From Saifulmujani.com: https://saifulmujani.com/efek-ekor-jas/

Harian Sederhana. (2018, Oktober 1). Dapil Cisari, PKS Depok Targetkan 2 Kursi. From Hariansederhana.com: https://www.hariansederhana.com/dapil-cisari-pks-depok-targetkan2-kursi/

Hasan, A. M. (2017, Februari 14). Kuatnya Sentimen Agama di Pilgub Jakarta. From Tirto.id: https://tirto.id/kuatnya-sentimen-agama-di-pilgubjakarta-ciZn

Humas DPP PKS. (2017, November 26). Presiden PKS Lantik Tim Pemenangan Pemilu 2019. Diambil kembali dari PKS.id: https://pks.id/content/presiden-pks-lantik-tim-pemenangan-pemilu2019

KPU Kota Depok. (2019). Rumah Pintar Pemilu, Info Pemilu, JDIH dan PPID KPU Kota Depok, Pengumuman Hasil Audit Laporan Penerimaan dan Pengeluaran Dana Kampanye Pemilihan Umum Tahun 2019. From Informasi dan Dokumentasi pada layanan kantor dan laman resmi KPU Kota Depok (https://kota-depok.kpu.go.id/)

Labolo, D. M., \& Ilham, T. S. (2015). Partai Politik Dan Sistem Pemilihan Umum Di Indonesia. Jakarta: PT. Raja Grafindo Persada.

Lindawati, D. S. (2013). Strategi Partai Politik Dalam Menghadapi Pemilu 2014. Jurnal Politicia, Vol. 4 No. 2.

Majelis Pertimbangan Pusat Partai Keadilan Sejahtera. (2008). Memperjuangkan Masyarakat Madani. Jakarta: DPP PKS.

Mansur, A. (2018, Oktober 14). PKS Targetkan Tembus Papan Atas di Pemilu 2019. Diambil kembali dari Republika.co.id: https://republika.co.id/berita/pgl1cu430/pks-targetkan-tembuspapan-atas-di-pemilu-2019

Muhtadi, B. (2012). Dilema PKS: Suara dan Syariah. Jakarta: KPG.

NAS. (2018, April 8). Presiden PKS: Masyarakat Perlu Pendidikan Politik. From Indopos.co.id:

https://indopos.co.id/read/2018/04/08/134078/presiden-pksmasyarakat-perlu-pendidikan-politik/

Neuman, W. L. (2014). Social Research Method: Qualitative and Quantitative Approach. Edinburgh: Pearson Education Limited. 
Nugroho, K. W. (2019, April 8). Rizieq: Saya Instruksikan FPI Kerja Sama dengan PKS Menangi Pemilu. From Kumparan NEWS: https://kumparan.com/kumparannews/rizieq-saya-instruksikan-fpikerja-sama-dengan-pks-menangi-pemilu-1qqhqG3IEpG/full

Putri, R. D. (2018, September 7). Takhta PKS yang Langgeng di Depok. Diambil kembali dari Tirto.id: https://tirto.id/takhta-pks-yang-langgeng-didepok-cXvS

Putri, R. D. (2019, Juni 13). Macet, Semrawut, Korupsi. Solusi Pemkot Depok: Jadi Kota Religius. Diambil kembali dari Tirto.id: https://tirto.id/macetsemrawut-korupsi-solusi-pemkot-depok-jadi-kota-religius-ecj4

Rahma, A. (2019, Maret 10). Isu Agama Dinilai Masih Jadi Andalan di Pemilu 2019. From Tempo.co: https://pemilu.tempo.co/read/1183731/isuagama-dinilai-masih-jadi-andalan-di-pemilu-2019

Ramadhan, B. (2017, Oktober 14). Ini Target-Target PKS di Pemilu 2019. From Republika.co.id:

https://republika.co.id/berita/nasional/politik/17/10/14/oxt0et330ini-targettarget-pks-di-pemilu-2019

Riana, F. (2018, Oktober 14). Gelar Konsolidasi Nasional, PKS Ingin Jadi Partai Papan Atas. Diambil kembali dari Tempo.co: https://pemilu.tempo.co/read/1136106/gelar-konsolidasi-nasionalpks-ingin-jadi-partai-papan-atas/full\&view=ok

Schroder, P. (2010). Strategi Politik. Jakarta: Freidrich Nauman Stiftung.

Sholeh, F. T. (2015). Manhaj Tarbiyah dalam Pendidikan Politik Kader Partai Keadilan Sejahtera (PKS). Jurnal Salam, Vol. 18 No. 1.

Siavelis, P. M., \& Morgenstern, S. (2008). Pathway to Power: Political Recruitment and Candidate Selection in Latin America. Pennsylvania: Pennsylvania University Press.

Sobalely, J. R. (2015). Kemenangan Partai Demokrasi Indonesia Perjuangan (PDI-P) pada Pemilihan Umum Legislatif 2014 di Kota Depok. Tesis. Depok: Ilmu Politik Fakultas Ilmu Sosial dan Ilmu Politik Universitas Indonesia.

Supriatna, I., Amin, M., \& Jasad, U. (2016). Dakwah Siyasah: Strategi Dakwah Partai Keadilan Sejahtera (PKS) dalam perjuangan Aspirasi Umat Islam. Jurnal Diskursus Islam, Vol. 4 No. 1. 
POLITICON : Jurnal Ilmu Politik Vol.3 No.1 ; Hal 34 - 59

Website : http://journal.uinsgd.ac.id/index.php/politicon ISSN : 2685-6670 ( Online )

Tanuwidjaja, S. (2010). Political Islam and Islamic Parties in Indonesia: Critically Assessing the Evidence of Islam's Political Decline. Jurnal Contemporary Southeast Asia, ISEAS-Yusof Ishak Institute.

Wiangga, L. S. (2017, Juli 27). PKS Siapkan Strategi Pemenangan Pemilu 2019. Diambil kembali dari Bisnis.com: https://kabar24.bisnis.com/read/20170727/15/675527/pks-siapkanstrategi-pemenangan-pemilu-2019 